\title{
The Relation of Dolomite Associated with Faults to the Stratigraphy and Structure of Central Kentucky
}

GEOLOGIGALSURVEX PROFESSIONALAAPER IISI-A

Prepared in cooperation with the

Kentucky Geological Survey

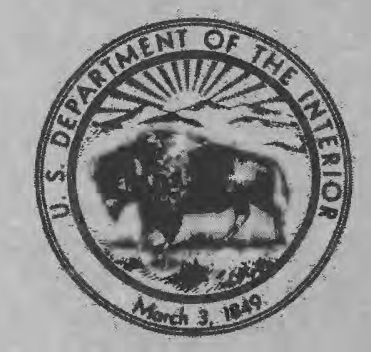





\section{The Relation of Dolomite Associated with Faults to the Stratigraphy and Structure of Central Kentucky}

By DOUglas F. B. Black, William C. MacQUOWN, JR., and RONAld J. DeHAAS

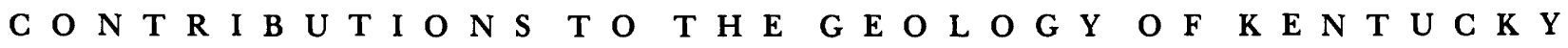

G E O L O G I C A L S S R V E Y P R O F E S S I O N A A L P A P P E R

Prepared in cooperation with the

Kentucky Geological Survey

$A$ discussion of field and laboratory studies

of newly discovered fault-associated

dolomite bodies found as a result

detailed geologic mapping

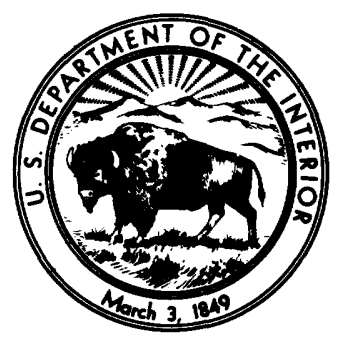




\title{
UNITED STATES DEPARTMENT OF THE INTERIOR
}

\author{
JAMES G. WATT, Secretary
}

GEOLOGICAL SURVEY

Doyle G. Frederick, Acting Director

Library of Congress Cataloging in Publication Data

Black, Douglas F B

The relation of dolomite associated with faults to the stratigraphy and structure of central Kentucky.

(Contributions to the geology of Kentucky) (Geological Survey professional paper ; 1151-A) Bibliography: p.

Supt. of Docs. no. : I 19.16:1151-A

1. Dolomites-Kentucky. 2. Faults (Geology)-Kentucky. 3. Geology-Kentucky. I. MacQuown, William Charles, Jr., 1915- joint author. II. - DeHaas, Ronald J., joint author. III. Kentucky. University. Geological Survey.

IV. Title. V. Series. VI. Series:

United States. Geological Survey. Professional paper ;

\section{Library of Congress Cataloging in Publication Data}

1151-A.

QE471.15.D6B55 552'.5 79-607049

For sale by the Superintendent of Documents, U.S. Government Printing Office Washington, D.C. 20402 


\section{CONTENTS}

\begin{tabular}{|c|c|}
\hline Page & \\
\hline A1 & 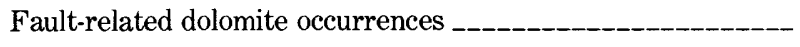 \\
\hline 1 & Representative examples of fault-related dolomite \\
\hline $\begin{array}{l}2 \\
2\end{array}$ & Laboratory investigations ________- \\
\hline 3 & Summary and conclusions _-_-_-_-_-_-_-_-_ \\
\hline 3 & 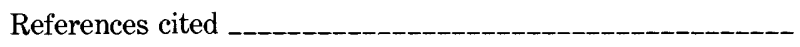 \\
\hline
\end{tabular}

Abstract

Introduction

Dolomite classification and features used in field indentification

Regional stratigraphy

Lithologic description of dolomite types

Regional geologic structure and relation to dolomite
References cited age

A9

9 17

\section{ILLUSTRATIONS}

FIGURE 1. Index map showing regional structural features in relation to study area

2. Schematic cross section, south-central to northern Kentucky showing stratigraphic relations and nomenclature of near-surface formations and schematic plot of fault-associated dolomite occurrences

3. Map showing fault-associated dolomite localities in relation to geologic structural fabric in the study area

4. Total-intensity aeromagnetic map of the study area shown in relation to dolomite occurrences and surface faults

5. Geologic map of part of the Winchester quadrangle that includes dolomite localities 8 and 11

6. View west at sample array BW-1 to BW-9

7. T-dolomite body at locality $8 \mathrm{~b}$

(1)

(1)

-

\section{TABLES}

TABLE 1. Structurally related dolomite occurrences 



\title{
THE RELATION OF DOLOMITE ASSOCIATED WITH FAULTS TO THE STRATIGRAPHY AND STRUCTURE OF CENTRAL KENTUCKY
}

\author{
By Douglas F. B. Black, William C. MacQuown, $\mathrm{Jr}^{1}{ }^{1}$, and Ronald J. DeHaAS ${ }^{2}$
}

\begin{abstract}
Two modes of origin have been determined for fault-related dolomite in limestone formations of central Kentucky. Dolomite bodies have been emplaced as grabens downfaulted from regionally dolomitized formations much higher in the stratigraphic section. Offset on these faults is as much as 800 feet, much greater than displacements of other faults in the area. Other dolomite bodies associated with faults resulted from inplace alteration of limestone country rock by solutions conducted along the faults. These bodies are elongate in plan view and are adjacent to the conduit faults, commonly on the downthrown sides.

The fault-related dolomite bodies are in the central Kentucky mineral district located on the highly faulted central part of the Jessamine Dome of the Cincinnati Arch where barite has been mined in the past from veins that also contain minor amounts of fluorspar, lead, and zinc. The veins occur in limestone and have a northerly strike. The dolomite is found chiefly along faults that strike northwest and contains only trace amounts of vug-fill barite locally.

Some of the dolomite lies along the major fault systems of the area that are known to displace Proterozoic basement rocks and to have been active intermittently during their history. The remaining dolomite bodies, including those found at each of two cryptoexplosive structures in the study area, lie along lineaments defined by geologically mapped structural features, such as swarms of faults, grabens, small steep-walled structural basins, and linear folds. We suggest that these structurally expressed lineaments, though defined by relatively minor disruption of the surface rocks, also reflect basement faults along which displacement has taken place periodically.

Circular cryptoexplosive structures, such as the Jeptha Knob and Versailles structures in this area, have been attributed to meteorite impacts by some geologists and to subterranean explosions by others who call the resulting structures cryptovolcanic. At the center of the Jeptha Knob disturbance, a horst was discovered that consists of dolomitized limestone, uplifted about 450 feet from its normal stratigraphic position. The horst is in direct fault contact with undolomitized carbonate rock. The dolomitic rock is derived from a unit that is nowhere else known to be dolomitized. In the absence of contradicting evidence, this fact, coupled with the apparent coincidence of both the Jeptha Knob and Versailles features and structural lineaments presumed to reflect deep-seated faults, suggests that the dolomitization is related to the structure, that it took place at depth
\end{abstract}

\footnotetext{
${ }^{1}$ University of Kentucky, Lexington. Ky. 40506

${ }^{2}$ University of Michigan, Ann Arbor, Mich. 48109
}

before uplift of the horst block, and that these structures are thererore more likely to be of cryptovolcanic rather than of meteorite-impact origin.

We further suggest that the structural lineaments defined by detailed geologic mapping may be loci for mineral deposits and (or) petroleum entrapments at depth, especially in areas where thick impervious shale formations cover the brittle solution-susceptible carbonate rock formations that are exposed and locally dolomitized in the central part of the Jessamine Dome. Minor amounts of oil were found in two zones in a shallow drill core and as vug fillings seen in the dolomite outcrop at the Stoner Branch locality.

\section{INTRODUCTION}

Anomalous local bodies of dolomite were found associated with many faults in the predominantly limestone terrane of central Kentucky (fig. 1) during the detailed geological mapping program conducted cooperatively by the Kentucky Geological Survey and the U.S. Geological Survey (USGS). Fossils found in some of these dolomite bodies during the early work led the geologists to think that all these bodies were downfaulted blocks derived from overlying Upper Ordovician and younger dolomite formations. Black (1974) determined that in some places the dolomitization was due to inplace alteration of limestone by solutions moving along faults and fractures. This interpretation was made first at the Stoner Branch locality in the Winchester Quadrangle where a body of dolomite is bounded on only one side by a fault. The dolomite is underlain by a quartz siltstone, the Garrard Formation, which, though its interstitial calcite cement has been locally dolomitized, was traceable along four stream valleys beneath the dolomitized limestone of the overlying formation. Thus, the possibility that the dolomite body had been downfaulted from higher dolomitic formations was ruled out. Syndepositional dolomitization was also considered, but this hypothesis was discarded later when an excavation revealed the nature of lateral gradation from dolomite to limestone. 


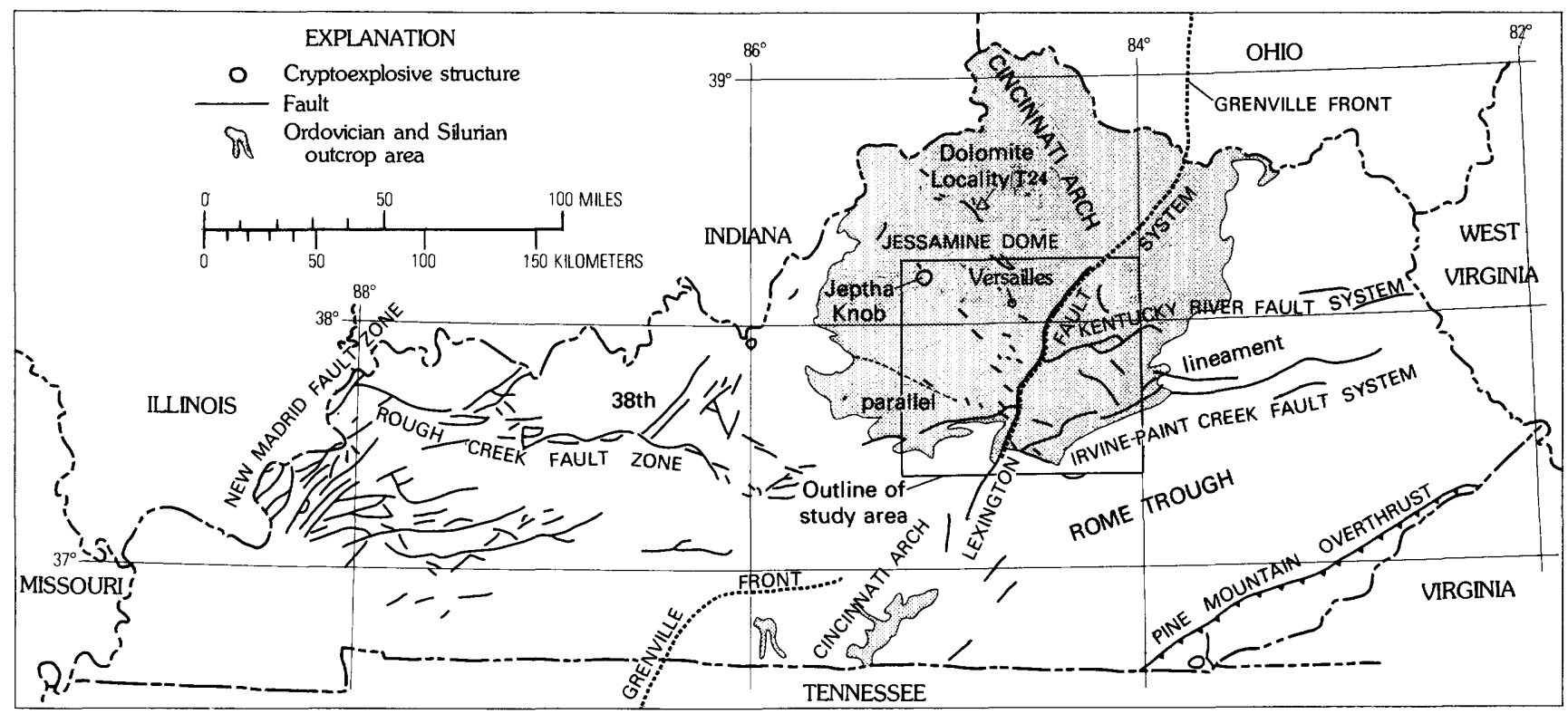

FIGURE 1.-Index map showing regional structural features in relation to study area. Central Kentucky faults sketched from recent geologic maps; others from Jillson (1929); Grenville Front in Ohio and southern Kentucky from Bayley and Muehlberger (1968). Map also shows location of dolomite localiaty $\mathrm{T}^{24}$.

Two means of emplacement are now recognized for the bodies of dolomite associated with faults in the region: grabens faulted down from younger dolomite formations and inplace dolomitization of limestone. We must distinguish between the two origins of dolomite to understand the geology of the area. This study deals chiefly with field relations and observations pertaining to the dolomites. It also briefly summarizes laboratory investigations being conducted by W. C. MacQuown, Jr., and R. J. DeHaas, and thermal maturity studies by A. E. Harris (USGS) and S. R. Jacobson (Chevron, U. S. A., Inc.). Results of chemical analysis are also presented.

\section{DOLOMITE CLASSIFICATION AND FEATURES USED IN FIELD IDENTIFICATION}

Dolomite in the study area has been divided into three types which are based in part on the classification system of Dunbar and Rodgers (1957). Stratiform regionally dolomitic formations and the dolomite blocks downfaulted from them are called S-dolomite. Tectonically related dolomitized rock is designated T-dolomite. The term "U-dolomite" is used for faultrelated dolomite of uncertain origin.

We now believe that, during the early part of the mapping program, certain dolomite bodies, such as those shown in the Coletown (Black, 1967) and Nicholasville (MacQuown, 1968) Quadrangles, were mapped incorrectly. Fault-associated bodies enclosed by Middle Ordovician formations exposed in the central Bluegrass area of the Jessamine Dome are very similar to the Upper Ordovician to Middle Devonian S-dolomites in outlying areas. This, coupled with a Silurian- or Devonian-age determination based on fossils at one of the Nicholasville localities, caused us to map all these bodies as grabens derived from the younger rocks. Subsequently, other bodies were found, and they, too, were all mapped as grabens until the discovery of T-dolomite was made at Stoner Branch in the Winchester Quadrangle. The earlier discovered bodies have since been reevaluated, and all subsequent discoveries evaluated by means of certain characteristics on which their present classification is based. These include (1) identifiable key fossils in the dolomite, (2) lithologies and relict features not completely destroyed by dolomitization, (3) position in recognizable stratigraphic sequences, (4) proximity to and obvious association with other dolomite bodies of known origin, and (5) observed gradation at boundaries between dolomite and limestone. Less positive classifications, which are queried in this report, are based on poorly preserved fossils and on the similarity of relict textures and sedimentary structures to like features in positively identified stratigraphic units.

\section{REGIONAL STRATIGRAPHY}

Rocks of Middle Ordovician age, the oldest exposed in Kentucky, crop out in the south-central part of the Jessamine Dome of the Cincinnati Arch (fig. 1). Successively younger strata, extending to rocks of Pennsylvanian age, crop out in an irregularly concentric pat- 
tern around the dome or extend southward and northward along the flanks of the arch. Figure 2 shows the lithologies and stratigraphic relationships of Ordovicianto Devonian-age formations that include the S-dolomite units discussed herein. The section, not drawn to scale, is a schematic representation of the surface and nearsurface stratigraphy between the south-central part of the dome northeastward to the Ohio River. Detailed descriptions of rocks along the belt of outcrop are given in the USGS geologic quadrangle reports.

The stratigraphic section shown in figure 2 is divided into three sequences on the basis of S-dolomite content. The lower sequence is made up partly of bedded dolomite and dolomitic limestone in that part of the High Bridge Group exposed in Kentucky and extends down to include thick subsurface dolomitic formations in the lower Paleozoic (not shown). These subsurface rocks are not germane to the subject of this paper except as a possible source of magnesium for tectonically controlled hydrothermal alteration of limestone to dolomite and are not discussed further. The outcropping part of the lower dolomitic sequence contains thick-bedded stratiform dolomite, chiefly in the Oregon Formation. It also includes micritic limestone that contains dolomite pods and stringers occurring as fillings of burrows and tracks in the original sediments or as thin laminae in parts of the Tyrone and Camp Nelson Limestones. The dolomite of the lower sequence probably formed during early diagenesis in a tidal-flat, supratidal, and highintertidal environment (Cressman and Noger, 1976).

The upper sequence includes S-dolomite of Late Ordovician, Silurian, and Devonian age. To the south, it consists of dolomite, dolomitic mudstone, and dolomitic shale. Northward, the sequence thins by intertonguing of the lower part with limestone units of the middle sequence as shown in figure 2. This sequence has been eroded in the central area of the Jessamine Dome but is exposed around the flanks. In these rocks, traces of fossils and relict bedding suggest that much of the dolomite was originally limestone deposited in a shallowwater subtidal environment very similar to that of the limestone and shale sequence below. Mud cracks in some beds indicate, however, that some of the sediment may have been dessicated by subaerial exposure at times and, thus, would have been partly intertidal or supratidal.

The middle sequence is virtually devoid of S-dolomite. It is made up of bioclastic limestone and shale. This sequence contains the isolated fault-related bodies of T-dolomite that are the principal subject of this report.

\section{LITHOLOGIC DESCRIPTION OF DOLOMITE TYPES}

S-dolomite constitutes a suite of several lithologic varieties. Some stratigraphic units are composed chiefly of indurated, very fine to fine sand-sized crystalline dolomite that crops out as minor ledges. Fresh rock is gray but has a slight greenish cast and locally is flecked with patches of bright green. It is generally weathered yellow, orange, and brownish red. In unweathered rock where the green color is indistinct, the dolomite is difficult to distinguish from limestone, and identification requires chemical staining or acid etching. The presence of interstitial calcite in some of the dolomitic rocks causes them to effervesce in $\mathrm{HCl}$ even more vigorously than fine-grained limestone varieties. Etched dolomite when treated with a solution of dilute $\mathrm{HCl}$ and alizarin red-S stain shows a rhombic-crystal mosaic pattern in which unstained rhombs are outlined by carmine-red staining of the interstitial calcite.

Other S-dolomite units are argillaceous carbonate rocks and can be divided into nonfissile dolomitic mudstone and dolomitic shale. These argillaceous rocks commonly weather to unctuous clay of various shades of greenish gray or locally reddish gray. The dolomitic mudstone contains very fine to fine rhombic dolomite crystals scattered through a matrix of aphanitic argillaceous material and silt-sized dolomite and sparse quartz particles. The apparent fissility of the dolomitic shale varies with the degree of weathering. In addition to clay minerals, the shale also contains scattered dolomite crystals and some quartz silt.

S-dolomite of the upper sequence is readily distinguishable by its coarser crystal size and darker color from the very finely crystalline to microcrystalline yellow dolomite of the lower sequence. Within the upper sequence, however, lithologic similarities make it difficult to differentiate the various formations and members except where they contain definitive fossils or locally definitive chert or where there is sufficient outcrop to establish a recognizable stratigraphic sequence.

$\mathrm{T}$-dolomite is remarkably similar to the S-dolomite of the upper sequence but is unlike the limestone from which it is derived. The descriptions given for the evenbedded resistant dolomite, dolomitic mudstone, and dolomitic shale of the upper S-dolomite sequence apply equally well to rocks found in the T-dolomite bodies. A minor exception is found in some of the $\mathrm{T}$-dolomite where local concentrations of pink to white coarse saddle-shaped crystals line cavities in finely crystalline rhombic dolomite and in partly dolomitized limestone.

\section{REGIONAL GEOLOGIC STRUCTURE AND RELATION TO DOLOMITE}

The location of the study area with respect to the major structural features of Kentucky is shown in figure 1 . The area encompassses the confluence of several major fault systems, the crest of the Jessamine Dome of the Cincinnati Arch, part of the east-northeast-trending 38th Parallel Lineament, the northwestern flank of the 


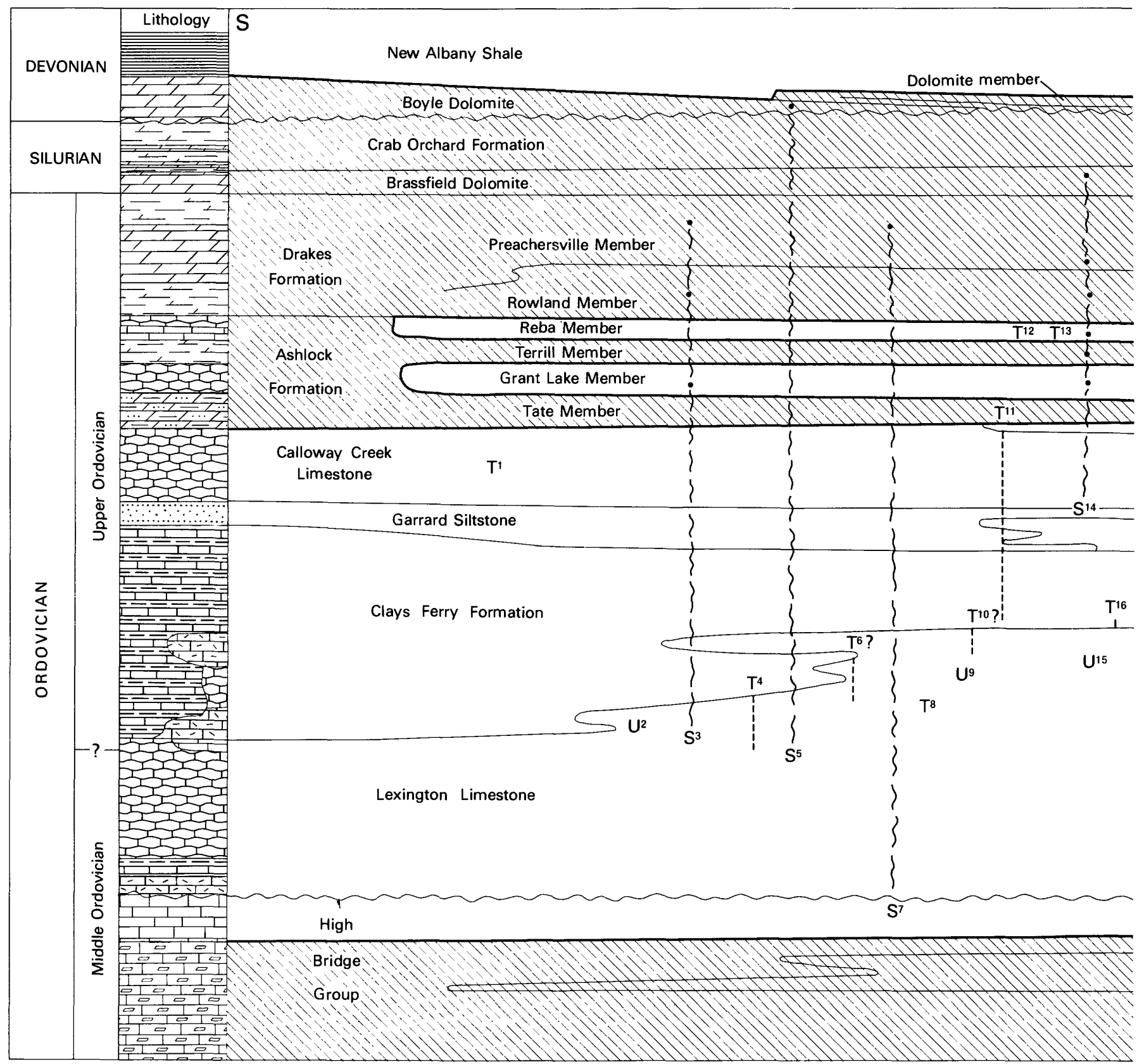

FigURE 2.-Stratigraphic relations and nomenclature of near-surface formations and schematic plot of fault-associated dolomite by genetic type tions of dolomite bodies with respect to adjacent rocks are shown by the letter symbols, queried where appropriate and keyed to locality numbers graben-emplaced S-dolomite and horst-emplaced T-dolomite; dots show original stratigraphic position of these bodies. Arbitrary lateral contacts

Rome Trough, the Jeptha Knob and Versailles Cryptoexplosive Structures and, in the basement, the northnortheast-trending Grenville Front. Regional dip off the arch is gentle, as much as 30 feet per mile toward the Appalachian Basin to the southeast and about 15 feet per mile northwesterly toward the Illinois Basin.

The shaded-relief image of geologic structure shown in figure 3 was constructed by means of modified dataprocessing techniques (Chavez and others, 1979) developed for the U.S. space program by the imageprocessing facility of the U.S. Geological Survey at Flagstaff, Ariz. Structure contour maps drawn on various stratigraphic horizons at a contour interval of 20 feet were traced on a vectoral digitizer, raster-scan converted to a pixel array wherein vertical values were assigned varying shades of gray, areally analyzed for steepness and direction of slope, and processed to portray the chosen direction and angle of illumination. Most 




(S, stratigraphic; T, tectonic; U, unknown), south-central and northern Kentucky. Shaded areas show regionally dolomitized units. Present posigiven in figures 1 and 3 and table 1. Dashed lines show range of T-dolomite occurrences. Wavy dashed lines show range of displacement of between units whose lithologies intergrade are shown by vertical dotted lines.

of the image expresses structure contours drawn on the top of the Tyrone Limestone of Middle Ordovician age. The various structure contour horizons shown in the southern part were extrapolated approximately to this horizon.

The major fault systems and linear folds that crosscut the study area are shown in figure 3 . Some of these are known from drill-hole and geophysical data to extend into the Proterozoic basement. The fault systems divide the area into major blocks that in turn are subdivided into minor blocks by structural lineaments. Some lineaments are also discernible in figure 4.

A variety of structural features are responsible for the lineaments. They include rectilinear to somewhat sinuous normal faults, swarms of en echelon normal and strike-slip faults, linear folds expressed by alined bends in the structure contours, and alinements of grabens and small closed structural depressions. The structural 


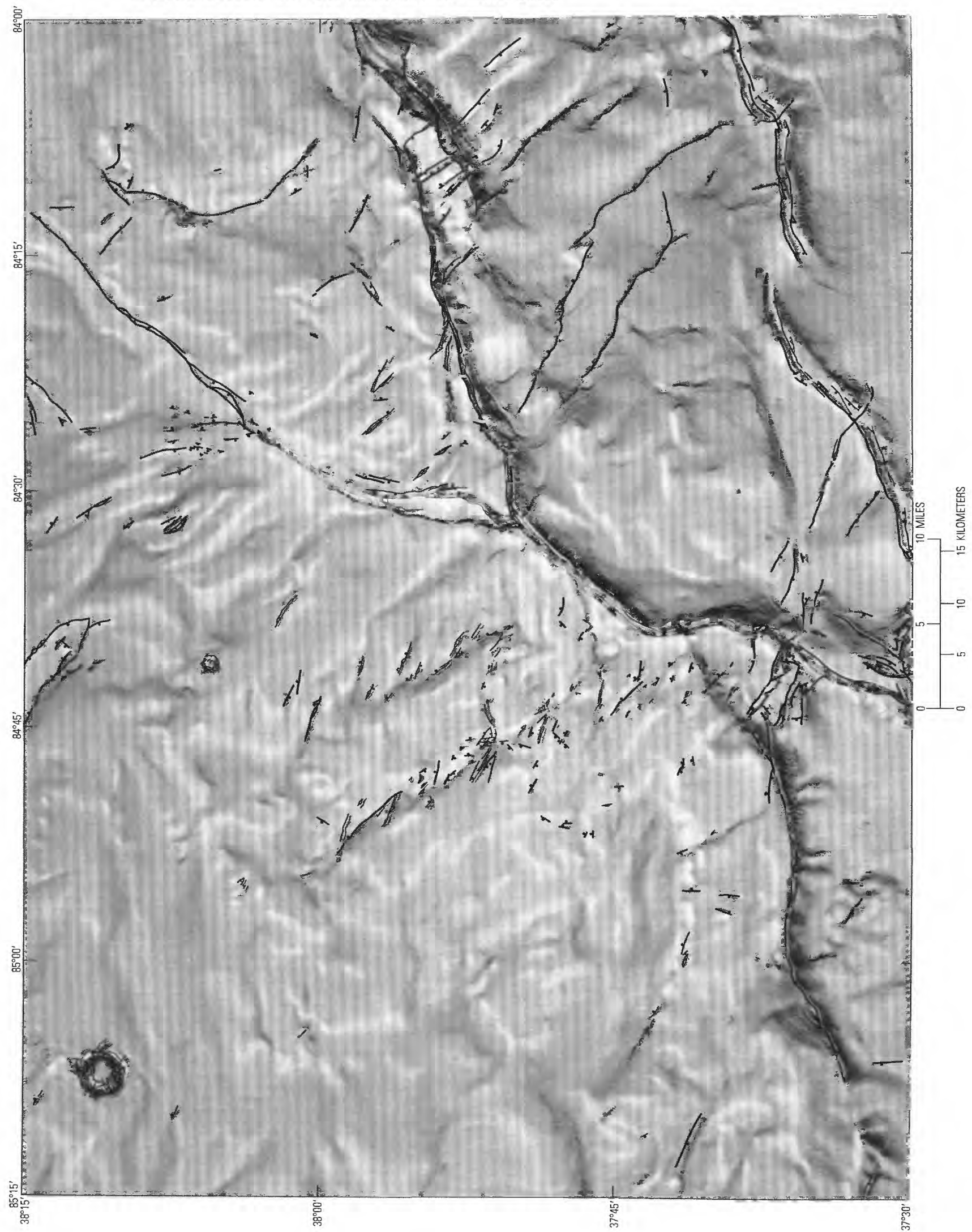









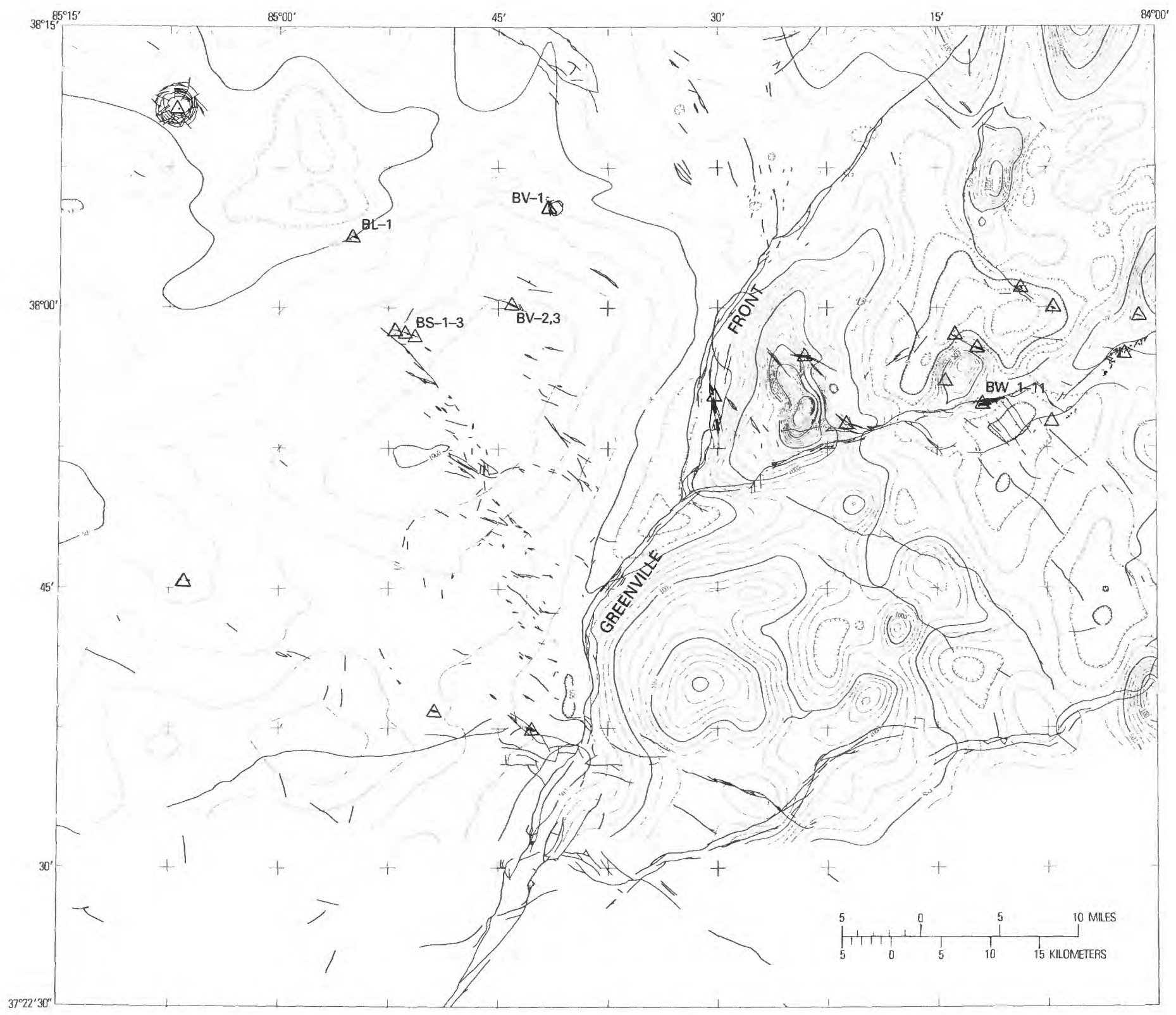

Figure 4.-Total-intensity aeromagnetic map of the study area shown in relation to dolomite occurrences and surface faults. Contour interval 100 gammas. Hachures indicate closed areas of lower magnetic intensity. Crosses show corners of 7.5-minute quadrangles. Labels designate sample localities of table 2 . Triangles show dolomite localities.

lineaments locally are also expressed topographically by alined patterns of sink holes (not shown) in areas underlain by limestone. Some of these coincide with mapped faults, and others probably formed along joint concentrations.
The orthogonal patterns of the lineaments, together with structure contour patterns in areas between them, suggest that the surface-rock deformation has been controlled by differential movement along faults that, in some places, are not exposed. From drilling, we know 
that some of these surface faults coincide with subsurface faults of much greater displacement than that shown in surface rocks. Thus, these lineaments are believed to define deep-seated blocks that apparently have shifted, both laterally and vertically with respect to one another, at various times during the complex tectonic history of the region.

Basement faults coincident with surface faults are also expressed on aeromagnetic and Bouguer gravity maps. Figure 4 is an aeromagnetic map of the study area by R. W. Johnson, Jr. (in Black and others 1976; 1977a, $\mathrm{b}, \mathrm{c}, \mathrm{d})$. The pronounced change in magnetic fabric across the north-northeast-trending Lexington Fault System shows a major discontinuity in the basement rock that projects toward, and is probably continuous with, the Grenville Front in southern Ohio, discussed by Bass (1960) and shown by Bayley and Muehlberger (1968) and Lidiak and Zeitz (1976). The changes in contour spacing show a marked decrease in magnetic intensity from north to south across a band that closely corresponds to the Kentucky River Fault System. This masking of basement-rock-induced magnetism is caused by increased thickness of the lower Paleozoic section on the downthrown side of that fault system, known from drill holes that extend to basement. The Kentucky River Fault System forms the northern limit of the Rome Trough. The Irvine-Paint Creek Fault System to the south is also known to be a growth fault, one in which concurrent displacement and sedimentation has occurred, and has an even greater increase in thickness in the lower Paleozoic section on its downthrown side. Limited aeromagnetic coverage prevents clear definition of this feature, however. As shown in figure 4, many of the dolomite bodies east of the Grenville Front appear to be clustered about several of the positive magnetic anomalies. Some dolomite bodies have no obvious associated magnetic anomalies, however, and any possible genetic relationship between the dolomite and rocks responsible for these anomalies could be determined only by deep drilling.

The dolomite bodies of the area are clearly related to faults of the major fault systems and structural lineaments. The T-dolomitization almost certainly has been effected by solutions conducted along faults and fractures and further extended along bedding planes. The source of the solutions is not known. They might have percolated downward from the same sources that caused the S-dolomitization of the Upper Ordovician to Middle Devonian carbonate rocks (fig. 2) or, just as reasonably, risen from subsurface sources along faults that we suggest have been propagated upward from basement-block margins. As noted earlier, thick sequences of dolomite that could be potential sources of magnesium are present in the subsurface. Evidence for and against each of the above hypotheses will be considered.

In either hypothesis, the association between dolomite and deep-seated faults indicated by the structural lineaments suggests that:

1. During the complex tectonic history of the region, periodic displacements along linear zones of weakness have created open spaces in relatively brittle carbonate rocks, some of which have been selectively dolomitized along the lineaments.

2. These same linear zones might be suitable for the emplacement of ore minerals, or entrapment of petroleum, or both, especially where thick, relatively plastic, and probably impervious shale overlies the solution-susceptible carbonate rocks.

The area of dolomite occurrence lies within the Central Kentucky Mineral District (Jolly and Heyl, 1964; Fohs, 1913; Robinson, 1931). An example of oil and gas accumulation along an elongate fault-related body of locally dolomitized and petroliferous rock in otherwise barren limestone is the Albion-Scipio field in Michigan (Levorsen, 1967).

\section{FAULT-RELATED DOLOMITE OCCURRENCES}

Thirty-three dolomite occurences related to faults are known in central Kentucky (table 1). All but one, reported by Jillson (1945) and shown as locality $\mathrm{T}^{24}$ in figure 1, were discovered during the cooperative mapping program and are shown in figure 3 . The mode of emplacement for each was determined by the field geologist who mapped the body.

\section{REPRESENTATIVE EXAMPLES OF FAULT-RELATED DOLOMITE}

Six of the 24 dolomite localities shown in table 1 have been selected as representative of dolomite occurrences in central Kentucky. Five of these are found in the area of the Winchester (Black, 1974) and Hedges (Black, 1975) Geologic Quadrangles. In addition, the dolomite at the center of the Jeptha Knob Cryptoexplosive Structure in the Waddy and Shelbyville Quadrangles (Cressman, 1975a, b) is discussed.

\section{T-DOLOMITE: STONER BRANCH LOCALITY 11}

At this locality, an elongate body of dolomite lies along the Boonesborough Fault of the Kentucky River Fault System where it is crossed by Stoner Branch (fig. 5). The dolomitized equivalent of the Calloway Creek Limestone and Garrard Siltstone below are downthrown about 300 feet against the middle and upper parts of the Lexington Limestone and the overlying lower part of the Clays Ferry Formation. Steeply dipping drag-folded beds of 
TABLE: 1.-Structurally related dolomite occurrences

[Lecality numbers and symbols depieting dolomite type are keyed to figs. 1-3]

\begin{tabular}{|c|c|c|}
\hline $\begin{array}{l}\text { Lexality No., dolomite } \\
\text { type geoslogie quati- } \\
\text { rangle, and reference. }\end{array}$ & Structural ocecurrence & Stratigraphic relatıons \\
\hline $\begin{array}{l}\text { 1, T, Cardwell } \\
\text { (Peterson, 1977). }\end{array}$ & $\begin{array}{l}\text { Narrow steep-walled } \\
\text { structural basin, } \\
\text { trend WNW }\end{array}$ & $\begin{array}{l}\text { Calloway Creek Limestone, fossiliferous, } \\
\text { dolomitized in part. }\end{array}$ \\
\hline $\begin{array}{l}\text { 2, U, Danville } \\
\text { (Cressman, } \\
\text { 1972a). }\end{array}$ & Graben, trend E. & $\begin{array}{l}\text { Dolomite and dolomite mudstone of unknown } \\
\text { stratigraphy downthrown against upper part of } \\
\text { Lexington Limestone and Clays Ferry Formation. }\end{array}$ \\
\hline $\begin{array}{l}\text { 3, S, Bryantsville } \\
\text { (Wolcott and } \\
\text { Cressman, 1971) } \\
\text { and Stanford } \\
\text { (Shawe and } \\
\text { Wigley, 1974). }\end{array}$ & Graben, trend NW. & $\begin{array}{l}\text { Preachersville and Rowland Members of Drakes } \\
\text { Formation downthrown against middle and } \\
\text { upper part of Lexington Limestone, } \\
\text { throw } 650 \mathrm{ft} \text { maximum. }\end{array}$ \\
\hline $\begin{array}{l}\text { 4, T, Nicholasville } \\
\text { (MacQuown, } \\
\text { 1968). }\end{array}$ & $\begin{array}{l}\text { Fault blocks of Lex- } \\
\text { ington Fault } \\
\text { System, trend N. }\end{array}$ & $\begin{array}{l}\text { Mostly dolomitized Clays Ferry Formation and } \\
\text { Lexington Limestone displaced max. } 150 \mathrm{ft} \\
\text { against middle part of Lexington Limestone, } \\
\text { Clays Ferry Formation, and Garrard Siltstone. }\end{array}$ \\
\hline $\begin{array}{l}\text { 5, S. Nicholasville } \\
\text { (MacQuown, } \\
\text { 1968). }\end{array}$ & Graben, trend $\mathrm{N}$. & $\begin{array}{l}\text { Dolomite of Silurian or Devonian age down- } \\
\text { thrown against middle part of Lexington } \\
\text { Limestone and Clays Ferry Formation, throw } \\
\text { between } 700 \text { and } 800 \mathrm{ft} \text {. }\end{array}$ \\
\hline $\begin{array}{l}\text { 6, 'T?, Coletown } \\
\text { (Black, 1967). }\end{array}$ & $\begin{array}{l}\text { Two connecting } \\
\text { grabens, trend } \\
\text { WNW and NW. }\end{array}$ & $\begin{array}{l}\text { Dolomite, probably altered Clays Ferry } \\
\text { Formation and upper part of Lexington } \\
\text { Limestone displaced no more than a few tens } \\
\text { of feet against middle to upper parts of } \\
\text { Lexington Limestone. }\end{array}$ \\
\hline $\begin{array}{l}\text { 7, S, Ford } \\
\text { (Black, 1968). }\end{array}$ & $\begin{array}{l}\text { Breccia-filled graben, } \\
\text { trend NW. }\end{array}$ & $\begin{array}{l}\text { Dolomite and limestone breccia; fragments } \\
\text { range from upper part of Drakes Formation } \\
\text { to Ashlock Formation. Greatest displacement } \\
\text { slightly more than } 800 \mathrm{ft} \text { against lowermost } \\
\text { part of Lexington Limestone and Tyrone } \\
\text { Limestone. }\end{array}$ \\
\hline $\begin{array}{l}\text { 8, T, Winchester } \\
\text { (Black, 1974). }\end{array}$ & $\begin{array}{l}\text { Graben }(8 \mathrm{a}) \text { and } \\
\text { nearby zone of } \\
\text { minor faults and } \\
\text { fractures }(8 \mathrm{~b}), \text { trend } \\
\text { NW. }\end{array}$ & $\begin{array}{l}\text { Dolomitized middle and upper parts of Lexing- } \\
\text { ton Limestone downthrown against middle } \\
\text { part of Lexington; graben at 8a displaced } \\
\text { several tens of feet, negligible displacement } \\
\text { of spheroidal body at } 8 \text { b (figs. } 3,5 \text {, and } 7 \text { ). }\end{array}$ \\
\hline $\begin{array}{l}\text { 9, U, Winchester } \\
\text { (Black, 1974). }\end{array}$ & Graben, trend NW. & $\begin{array}{l}\text { Dolomite of unknown stratigraphy downthrown } \\
\text { against upper part of Lexington Limestone, } \\
\text { displacement not known. }\end{array}$ \\
\hline $\begin{array}{l}\text { 10, 'T?, Winchester } \\
\text { (Black, 1974), }\end{array}$ & -_-_do_______ & $\begin{array}{l}\text { Undolomitized Clays Ferry Formation and } \\
\text { dolomitized upper part of Lexington } \\
\text { Limestone(?) downfaulted } 100 \text { ft(?) against } \\
\text { Lexington Limestone. }\end{array}$ \\
\hline
\end{tabular}

11, T, Winchester (Black, 1974).
Boonesborough fault, trend ENE.
Extensive elongate body that includes dolomitized Calloway Creek Limestone, Garrard Siltstone, and Clays Ferry Formation downthrown $300 \mathrm{ft}$ against undolomitized Lexington Limestone. Dolomite grades laterally to undolomitized equivalent lithologies at varying distances from fault (figs. 3 and 5).
On structural lineament that includes Bardstown monocline. Locality includes three separate dolomite bodies.

Originally mapped as Urakes Formation requiring throw of about $600 \mathrm{ft}^{\mathrm{t}}$.

At intercept of NW-trending lineament and Brumfield fault.

Grabens within Lexington fault system originally mapped as Drakes Formation requiring displacement of 400-600 ft. Small displacement now assumed. Five separate dolomite bodies.

Lithology resembles that of Brassfield Dolomite or dolomitic Bisher Limestone but could be Boyle Dolomite. Included fossils tentatively identified as Silurian or Devonian.

Relict bedding character and possible local intergradation with limestone suggest T-dolomite. Originally mapped as Irakes Formation requiring displacement of about $600 \mathrm{ft}^{\mathrm{\prime}}$. Small displacement now assumed. Two separate but adjoining dolomite bodies.

Part contains identifiable fossils, part unidentifiable dolomite. 'Two separate dolomite bodies.

Ascending solutions dolomitized spheroidal body in fault zone. Graben originally mapped as U-dolomite. See text discussion. Two separate dolomite bodies.

Lies along connecting fault that also adjoins locality $\mathrm{T}^{\mathbf{1 0}}($ ?). See text discussion.

Fault relations are obscure. Lexington designation based on lithology and brachiopod indentification. Bryozoan identification suggests possible displacement from Calloway Creek Limestone. See text discussion. Two separate dolomite bodies.

Local petroleum hydrocarbons in vugs. Section dolomitized to tota depth penetrated by diamond-drill core hole. See text discussion. 
TABLE 1.-Structurally related dolomite occurrences-Continued

\begin{tabular}{|c|c|c|c|}
\hline $\begin{array}{l}\text { Locality No., dolomite } \\
\text { type geologic quad- } \\
\text { rangle, and reference }\end{array}$ & Structural occurrence & Stratigraphic relations & Comments \\
\hline $\begin{array}{l}\text { 12, T, Winchester } \\
\text { (Black, 1974) } \\
\text { and Hedges } \\
\text { (Black, 1975). }\end{array}$ & $\begin{array}{l}\text { Eagle Nest fault, } \\
\text { trend NE. }\end{array}$ & $\begin{array}{l}\text { Multiple outcrops of Reba Member of Ashlock } \\
\text { Formation, selectivity dolomitized as much } \\
\text { as } 4,000 \mathrm{ft} \text { from fault, grades laterally to } \\
\text { limestone, underlying units not dolomitic, } \\
\text { overlying units S-dolomite. Downfaulted } 200 \mathrm{ft} \\
\text { against undolomotized Calloway Creek } \\
\text { Limestone. }\end{array}$ & $\begin{array}{l}\text { Faulting and dolomitization pattern } \\
\text { similar to, and en echelon with, } \\
\text { locality } \mathrm{T}^{13} \text {. See text discussion. }\end{array}$ \\
\hline $\begin{array}{l}\text { 13, T, Hedges } \\
\text { (Black, 1975). }\end{array}$ & $\begin{array}{l}\text { Ruckerville fault, } \\
\text { trend NE. }\end{array}$ & $\begin{array}{l}\text { Reba Member of Ashlock selectivity dolomitized } \\
\text { as above (locality } \mathrm{T}^{12} \text { ). }\end{array}$ & $\begin{array}{l}\text { See above, locality } \mathrm{T}^{\mathbf{1}} \text {. See text } \\
\text { discussion. }\end{array}$ \\
\hline $\begin{array}{l}\text { 14, S, Hedges } \\
\text { (Black, 1975). }\end{array}$ & $\begin{array}{l}\text { Megabreccia graben, } \\
\text { trend NW. }\end{array}$ & $\begin{array}{l}\text { Several large blocks of S-dolomite and limestone } \\
\text { derived from recognized formations from } \\
\text { Brassfield Dolomite to Grant Lake Mem- } \\
\text { bers of Ashlock Formation downthrown max. } \\
\text { of } 500 \mathrm{ft} \text { against lower part of Calloway Creek } \\
\text { Limestone and Garrard Siltstone. }\end{array}$ & See text discussion. \\
\hline $\begin{array}{l}\text { 15, U, Hedges } \\
\text { (Black, 1975). }\end{array}$ & Graben, trend NW. & $\begin{array}{l}\text { Dolomitic shale, dolomitic mudstone, and dolo- } \\
\text { mite of unknown stratigraphy displaced } \\
\text { against upper part of Lexington Limestone. }\end{array}$ & $\begin{array}{l}\text { Dolomitic shale dominant, lithologically } \\
\text { similar to Drakes Formation (S-dolo- } \\
\text { mite?) or could be dolomitized Clay's } \\
\text { Ferry Formation ('T-dolomite). }\end{array}$ \\
\hline $\begin{array}{l}\text { 16, T, Austerlitz } \\
\text { (Outerbridge, } \\
\text { 1975). }\end{array}$ & $\begin{array}{l}\text { Austerlitz Fault Zone, } \\
\text { curvilinear, trend } \\
\text { NW to N. to NE. }\end{array}$ & $\begin{array}{l}\text { Dolomite in elongate body mapped at high angle } \\
\text { to fault, replaces Clays Ferry Formation and } \\
\text { upper part of Lexington Limestone. }\end{array}$ & \\
\hline $\begin{array}{l}\text { 17, T?, Salvisa } \\
\text { (Cressman, } \\
\text { 1968). }\end{array}$ & Graben, trend NW. & Undolomitized Clays Ferry Formation. & $\begin{array}{l}\text { Relict bedding and poorly preserved } \\
\text { fossils in dolomite resemble those } \\
\text { found in adjacent Lexington Lime- } \\
\text { stone on upthrown sides and also in } \\
\text { graben. }\end{array}$ \\
\hline $\begin{array}{l}\text { 18, T?, Salvisa } \\
\text { (Cressman, } \\
\text { 1968). }\end{array}$ & Graben, trend NW. & $\begin{array}{l}\text { Dolomitized middle part of Lexington Lime- } \\
\text { stone(?) downthrown 10-20 ft against } \\
\text { undolomitized middle part of Lexington } \\
\text { Limestone. }\end{array}$ & $\begin{array}{l}\text { Originally mapped as Drakes Forma- } \\
\text { mation. Present interpretation based } \\
\text { on similarity of relict bedding and } \\
\text { fossils to adjacent middle part of } \\
\text { Lexington Limestone. }\end{array}$ \\
\hline $\begin{array}{l}\text { 19, S? Salvisa } \\
\text { (Cressman, } \\
\text { 1968). }\end{array}$ & _-_-_do_____-_-_ & $\begin{array}{l}\text { Drakes Formation. Downthrown max. } 550 \mathrm{ft} \\
\text { against Clays Ferry Formation and upper part } \\
\text { of Lexington Limestone. }\end{array}$ & $\begin{array}{l}\text { Interbedded dolomitic mudstone and } \\
\text { dolomite similar to that of Drakes } \\
\text { Formation. }\end{array}$ \\
\hline $\begin{array}{l}\text { 20, T?, Versailles } \\
\text { (Black, 1964). }\end{array}$ & _-_do__._-_-_ & $\begin{array}{l}\text { Partly dolomitized(?) Clays Ferry Formation and } \\
\text { dolomitized upper part of Lexington Lime- } \\
\text { stone downthrown as much as } 100 \mathrm{ft} \text { against } \\
\text { middle part of Lexington Limestone. }\end{array}$ & $\begin{array}{l}\text { T-dolomite interpretation based on } \\
\text { relict bedding and character of } \\
\text { poorly preserved fossils. }\end{array}$ \\
\hline $\begin{array}{l}\text { 21, U, Versailles } \\
\text { (Black, 1964). }\end{array}$ & $\begin{array}{l}\text { Versailles Crypto- } \\
\text { explosive Structure. }\end{array}$ & $\begin{array}{l}\text { Dolomite as large float block of unknown } \\
\text { stratigraphy overlying cryptoexplosive breccia } \\
\text { in ring graben that displaces upper part of } \\
\text { Lexington Limestone max. of } 80-100 \mathrm{ft} \\
\text { against middle part of Lexington Limestone } \\
\text { peripheral to the structure. }\end{array}$ & $\begin{array}{l}\text { Breccia not dolomitized where } \\
\text { sampled (BV-1, table } 2)\end{array}$ \\
\hline $\begin{array}{l}\text { 22, T?, Lawrence- } \\
\text { berg (Cressman, } \\
\text { 1972b). }\end{array}$ & Graben, trend NW. & $\begin{array}{l}\text { Dolomitized Clays Ferry Formation(?) down- } \\
\text { thrown } 50-100 \mathrm{ft} \text { ? against Clays Ferry For- } \\
\text { mation and upper part of Lexington } \\
\text { Limestone. }\end{array}$ & $\begin{array}{l}\text { Interbedded dolomite and dolomitic } \\
\text { mudstone. Originally mapped as } \\
\text { Drakes Formation S-dolomite. }\end{array}$ \\
\hline $\begin{array}{l}\text { 23, T, Waddy } \\
\text { (Cressman, } \\
\text { 1975a). }\end{array}$ & $\begin{array}{l}\text { Jeptha Knob crypto- } \\
\text { explosive structure. }\end{array}$ & $\begin{array}{l}\text { Dolomitized lower part of Lexington Limestone } \\
\text { upfaulted } 300-450 \mathrm{ft} \text { against Clays Ferry } \\
\text { Formation. Uncomformably overlain by } \\
\text { Brassfield Dolomite that is not affected by } \\
\text { structure. Brassfield normally more than } 800 \mathrm{ft} \\
\text { higher in section }\end{array}$ & $\begin{array}{l}\text { Identification of lower part of Lexing- } \\
\text { ton (Logana Member) based on } \\
\text { fossils and lithology. Logana not } \\
\text { dolomitized elsewhere. Dolomitiza- } \\
\text { ation probably structurally related. } \\
\text { Rocks surrounding horst are not } \\
\text { dolomitized. See text discussion. }\end{array}$ \\
\hline $\begin{array}{l}\text { 24, T, Monterey } \\
\text { (Moore, 1977). }\end{array}$ & $\begin{array}{l}\text { Normal fault, trend } \\
\text { NW. }\end{array}$ & $\begin{array}{l}\text { Dolomitized Kope Formation and Clays Ferry } \\
\text { Formation downthrown against Kope and } \\
\text { Clays Ferry, minor throw. }\end{array}$ & $\begin{array}{l}\text { T-dolomite classification based on } \\
\text { USGS fossil identifications. Body } \\
\text { originally described by Jillson (1945) } \\
\text { as Silurian dolomitic formations. } \\
\text { Cited fossil identifications (Berry and } \\
\text { Boucot, 1970, p. 240) also gave } \\
\text { Silurian age. Their fossil collections } \\
\text { not located, however. }\end{array}$ \\
\hline
\end{tabular}




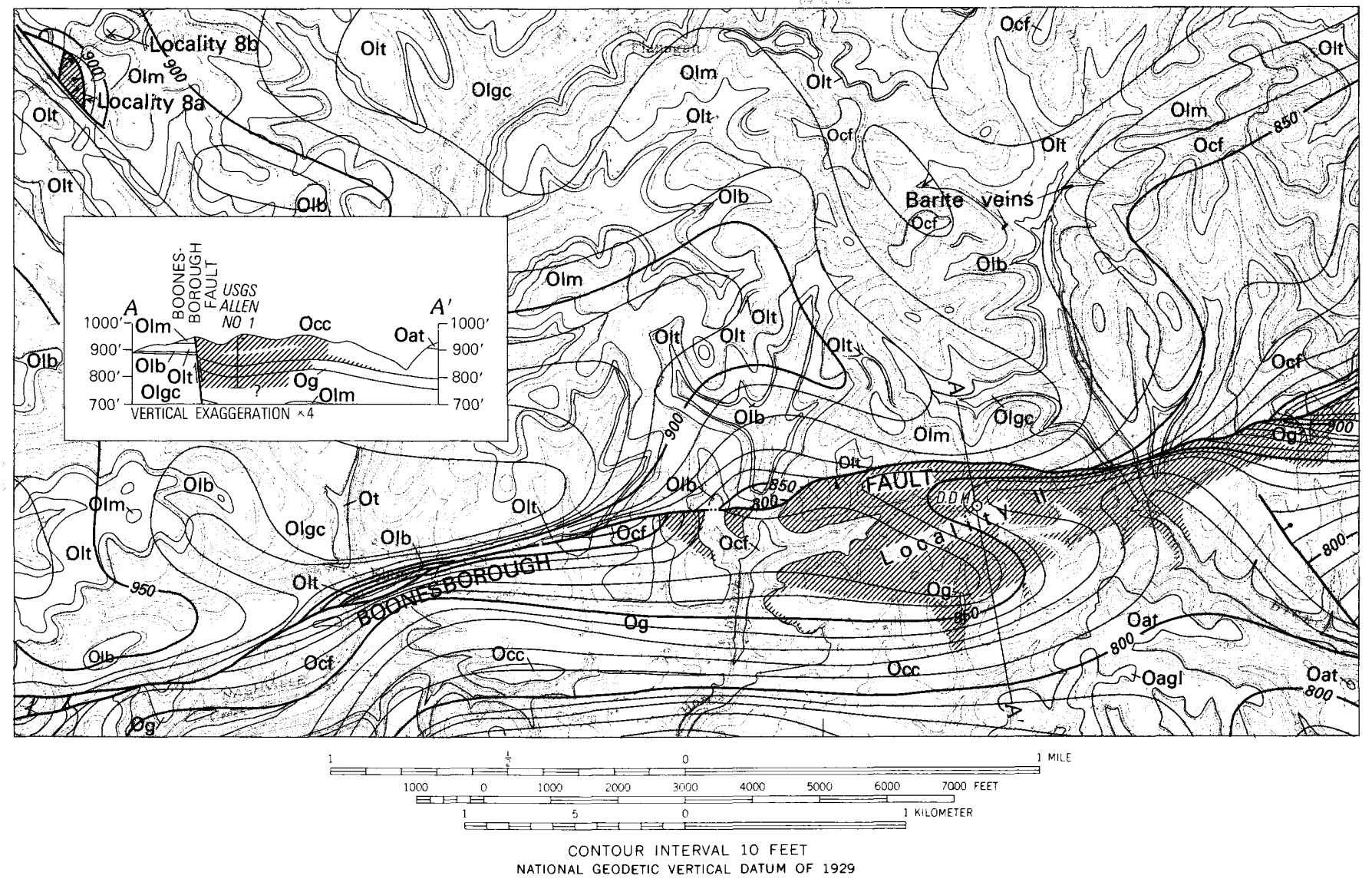

EX P L A N A T I O N
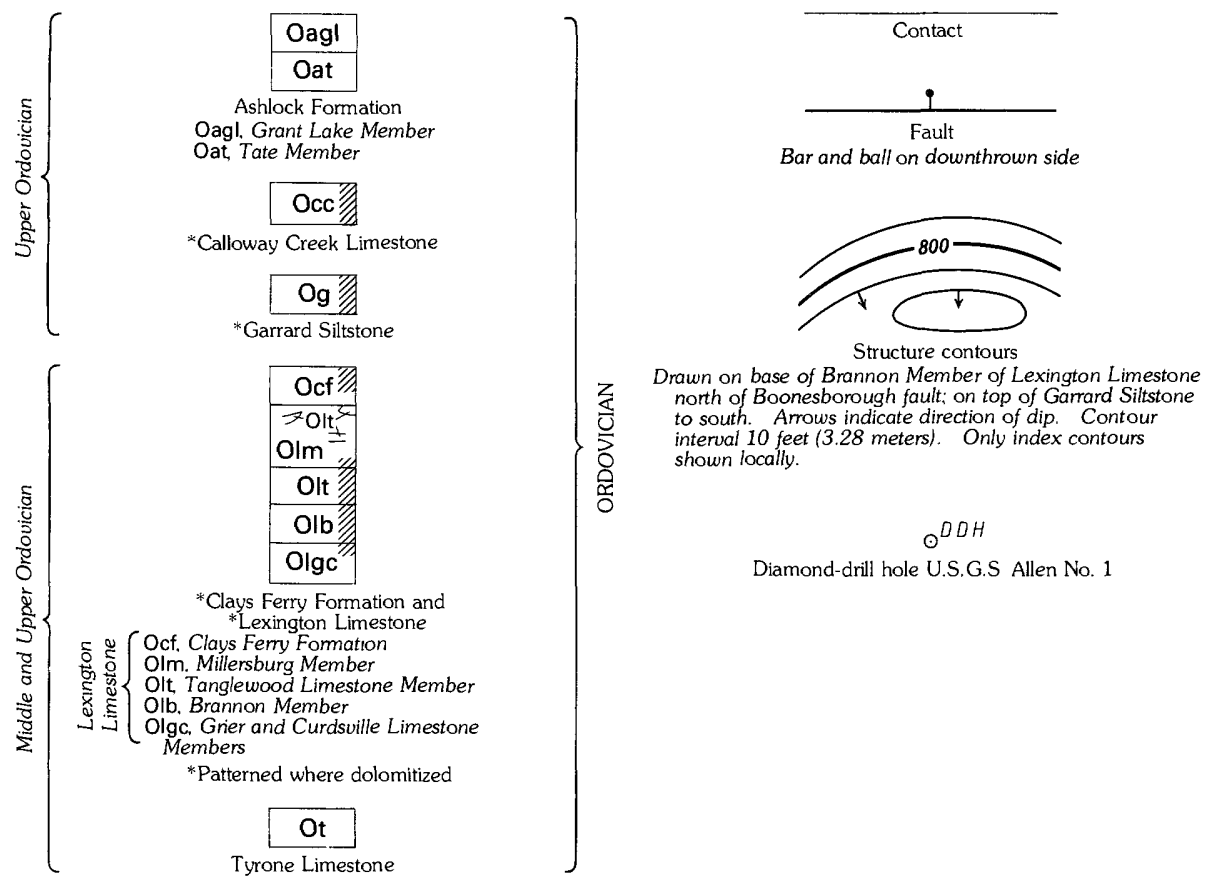

FIgURE 5.-Part of the Winchester Quadrangle that includes dolomite localities 8a, 8b, and 11 . 


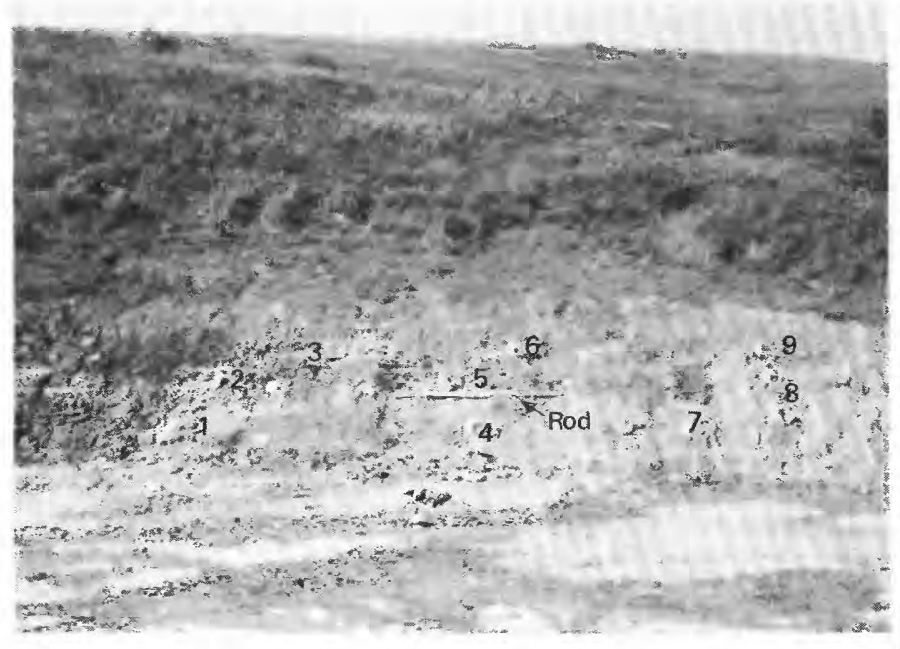

Figure 6.-View west at sample array BW-1 to BW-9. Samples to left are essentially unaltered Calloway Creek Limestone; middle samples are partly dolomitized; samples to right are completely dolomitized. Throughgoing shale interbeds were dug out to establish exact correlation of sampled limestone and dolomite beds. Stadia rod is 13 feet long.

micrograined limestone immediately adjacent to the fault may belong to the Clays Ferry Formation.

The limestone on the upthrown side contains widely disseminated small pods of dolomite, but in quantities not unusual regionally. On the downthrown side, however, the Calloway Creek Limestone is almost completely dolomitized throughout an area, about 2 miles long and as much as 0.5 mile wide, that parallels and abuts the fault. A tongue of dolomite locally extends as much as 4,000 feet from the fault into the enclosing undolomitized limestone. The quartz silt of the underlying Garrard Siltstone is unaffected by the dolomitization, but its normally calcitic cement is locally dolomitized. About 40 feet of the underlying Clays Ferry Formation also is dolomitized to total depth of penetration in the USGS Allen No. 1 diamond-drill core (fig. 5). Thus dolomitization may extend to much greater depth.

Field relations indicated that the dolomite body was not a graben. The Garrard was traced in four drainages beneath the almost completely dolomitized Calloway Creek Limestone. The continuity of the Garrard showed that the dolomite could not have been downfaulted from S-dolomite formations of the upper dolomite sequence.

The possibilty that these field relations could be explained as a structurally controlled depositional dolomitic facies of the Calloway Creek was also examined. Tongues of limestone, bounded by dolomite above and below, extend as much as 1,500 feet into the dolomitic zone from the unaltered part of Calloway Creek. These limestone tongues, also found in the drill core, are shown on the map and cross section (fig. 5). However, close inspection of outcrops close to the area of total dolomitization showed partial dolomitization of the limestone and an abrupt lateral gradation between the two rock types. This was best shown in a stock-pond excavation shown in figure 6 . Here, limestone in a given. bed grades laterally to dolomite within a few yards. Three separate resistant beds and intervening shale beds were traced across the transition zone between essentially unaltered limestone to the south (left set of three samples in sample array of fig. 6) and the completely dolomitized, stratigraphically equivalent beds about 40 feet to the north. Chemical analyses of the resistant beds, samples $\mathrm{BW}-1$ through $\mathrm{BW}-9$, are shown in table 2.

The Calloway Creek Limestone where not dolomitized includes a suite of lithologic types, generally some shade of gray and coarsely to finely bioclastic, that contains common to abundant whole fossils and large fossil fragments in most beds and partings and very thin interbeds of gray calcareous shale. Much of the rock is irregularly bedded to nodular, but some zones consist of even-bedded limestone and very thin shale interbeds. At Stoner Branch, the coarser limestone is altered to a medium- to coarse-crystalline mosaic of rhombic dolomite cemented by calcite; locally, coarse sparry calcite fillings and replacements postdate the dolomite. Most dolomite in surface exposures is weathered orange or yellow, at places flecked with red and green patches. Where fresh, the dolomite is gray and very similar in color to unaltered limestone. Megafossils are commonly obliterated in the dolomite or are seen as sparse ghosts outlined by opaque mineral concentrations, commonly pyrite. Crinoid columnals and plates and rare colonial corals, though dolomitized, are locally preserved as are phosphatic fillings of small gastropods and bryozoan zooecia and locally abundant phosphatic conodonts. The finer grained limestone is altered to finely crystalline dolomite or, where argillaceous, to dolomitic mudstone or locally very fissile dolomitic shale containing fine rhombic crystals disseminated throughout. Mudstone and shale are medium to dark gray and weather greenish gray or locally reddish gray. Original bedding in the limestone is irregular, hackly, or nodular, in part varying with size and type of enclosed megafossils and quantity of mud support. It is largely destroyed in the dolomitized equivalent, which is mostly thin and even bedded. Relict bedding is seen locally where ferruginous partings are preserved.

Cavity fillings of coarsely crystalline minerals that include barite, dolomite, and calcite have been found in outcrop at a few localities in the dolomitized rock. Barite veins were found north of the Stoner Branch area (fig. 5) but are regional in occurrence and not demonstrably related to the dolomitization. One mineralized cavity containing barite was found at a depth of 171 feet in the 


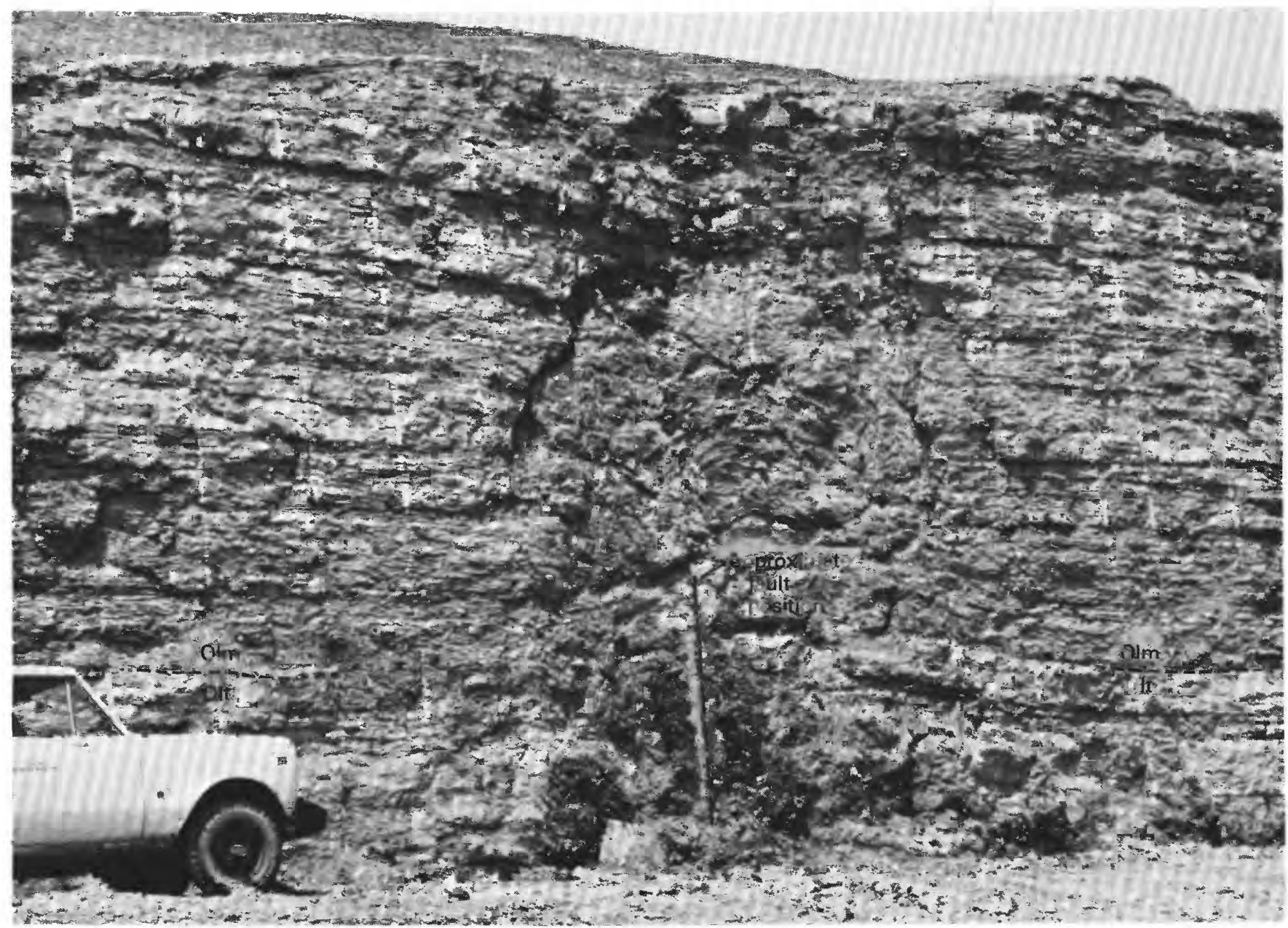

FIgure 7. - T-dolomite body at locality 8b. Minor fault displaces the Millersburg (Olm) and Tanglewood Limestone (01t) Members of the Lexington Limestone, downthrown side to the left. View northwest, Kentucky Highway 627, Winchester Quadrangle, Ky.

Allen No. 1 drill core. Two oil-bearing zones were penetrated by the drill, and tarry accumulations were found in cavities in outcropping dolomite and partly dolomitized limestone.

\section{T-DOLOMITE: LOCALITY 8}

The dolomite body at locality $8 \mathrm{a}$ (fig. 5) was originally mapped as a graben containing U-dolomite. Subsequent to the publication of the geological quadrangle (Black, 1974), a new roadcut in the Millerburg and Tanglewood Limestone Members of the Lexington Limestone exposed the dolomite body at locality $8 \mathrm{~b}$ (fig. 7). As at Stoner Branch, field relations here show that this body, too, is T-dolomite and that dolomitizing solutions have been conducted by faults, but, in addition, there is strong indication that the solutions responsible for dolomitization have risen from below.

The dolomitized body at $8 \mathrm{~b}$ appears to be roughly hemispherical or lensoid around a fault of small dis- placement that is restricted to the lower part of the roadcut. In contrast to the general observation that the downthrown sides of faults are preferentially dolomitized in most Kentucky occurrences, very little displacement is indicated here, and both sides are altered at approximately equal distances from the fault. We have no explanation for the apparent preference. The fact that the conduit fault and fracture system here does not offset the overlying surface rocks suggests that the faulting and associated dolomitization died out at this point. It is also possible that such a small displacement may have resulted from collapse caused by shrinkage brought about by dolomitization.

Features indicating shrinkage include curved fractures peripheral to the body and calcite-filled gash fractures at a slightly greater distance from it; increased porosity near its center where open, as well as partly filled, fractures and vugs are present; and synclinal sag of throughgoing beds above the body.

Minerals lining cavities in this body include dolomite, 
mostly as pink to white large saddle-shaped crystals, some sparry calcite, barite, pyrite, and limonite pseudomorphous after pyrite. Most of the dolomite is of the rhombic-mosaic variety. Near the center of the body, some of the rhombic dolomite shows draped bedding, interpreted as eroded dolomite crystals that make up a sediment that has been redeposited above a constriction in a solution-enlarged cavity. The bedding in the sediment is locally drag folded, presumably as a result of further settling. The roadcut face opposite the illustrated exposure contains a narrow zone of dolomitization along a joint.

Though the dolomitizing solutions could have descended elsewhere and moved laterally along the fault and associated fractures, no evidence was found along strike that suggested this. A more reasonable assumption is that the fault conduits feeding both the bodies at localities $8 \mathrm{a}$ and $8 \mathrm{~b}$ are interconnected at depth and that the dolomitizing solutions, probably hydrothermal, rose from below. For this reason, after the discovery at locality $8 \mathrm{~b}$, the body at $8 \mathrm{a}$ was reclassified as T-dolomite. The reclassification was supported by the presence of chert float of the Brannon Member, a unit in the middle of the Lexington Limestone, now thought to be nearly in place and preserved as residuum. The Brannon occurs close by on the upthrown side of one of the bounding faults and is also preserved in the downthrown dolomite and dolomitic mudstone at locality 8a. Maximum displacement of no more than a few tens of feet is, therefore, indicated for this graben, and major displacement from S-dolomite formations above is ruled out.

\section{T-DOLOMITE: LOCALITIES 12 AND 13}

At these localities, the Reba Member of the Ashlock Formation has been selectively dolomitized in two areas adjacent to the Eagle Nest and Ruckerville Faults, en echelon faults of the Kentucky River Fault System (Winchester and Hedges Quadrangles; Black, 1974, 1975). Complete dolomitization extends laterally to a maximum of 4,000 feet from the faults and partial dolomitization of the member extends more than 1,000 feet farther. The overlying rocks are all regional S-dolomites extending as high as a dolomitic member (the "Duffin" or "Ravenna" of earlier workers) in the basal part of the Devonian New Albany Shale (fig. 2). The Terrill Member of the Ashlock immediately underlying the Reba is also an S-dolomite consisting of dolomitic mudstone and shale. The Grant Lake Member of the Ashlock that directly underlies the Terrill is nowhere dolomitized, not even immediately adjacent to the faults, though its lithology would appear to be as susceptible to dolomitization as the Reba.

The Reba Member in this area consists of a basal micrograined limestone (calcisiltite to micrite) common- ly containing ostracodes and some cephalopods. The micrograined limestone is overlain by a zone of nodular brachiopodal and bryozoan limestone and some shale partings. This zone is locally overlain by a few feet of fossil-fragmental calcarenite. The argillaceous nodular limestone is dolomitized at greatest distance from the fault, the upper calcarenite at intermediate distance, and the lower micrograined limestone at least distance. The mapped extent of dolomitization represents only the area in which the rock is completely dolomitized (Black, 1975).

The suite of dolomite types found in the dolomitized Reba resembles types found in the upper S-dolomite sequence just above. However, the dolomitization in the Reba is classified as tectonic because of its obvious affinity to the two faults. Undolomitized Reba crops out in the graben at locality 14 to the north.

We do not know the time or means of emplacement of dolomite in the formations of the upper S-dolomite sequence. Because of the widespread distribution of dolomite, the possibility that it could be the product of fault-related hydrothermal solutions seems unlikely. Early diagenetic or syndepositional regional dolomitization would seem more probable. Yet, selective dolomitization of the Reba Member, occurring as it does sandwiched between the dolomitic Terrill mudstone and the remainder of the overlying upper S-dolomite sequence, suggests that the same dolomitizing solutions responsible for alteration of the upper S-dolomite sequence might have percolated downward along the Eagle Nest and Ruckerville Faults and been responsible for the local dolomitization. The downward migration of the solution may have been restricted by an impervious seal afforded by the shaly Terrill Member. This contrasts with the upward migration indicated at locality 8 .

\section{FAULT-RELATED S-DOLOMITE: LOCALITY 14}

The west-northwest-trending graben at this locality contains a megabreccia consisting of huge blocks, some several hundred feet across, downfaulted against the lower part of the Calloway Creek Limestone and upper part of the Garrard Siltstone. The blocks are partly S-dolomite and dolomitic shale and partly limestone. They are tilted and separated by crossfaults within the graben. At places, the stratigraphic sequence within a single block can be determined. Dolomitic formations identified include from oldest to youngest: the Terrill Member of the Ashlock Formation, the Rowland Member and part of the Preachersville Member of the Drakes Formation, and the Brassfield Dolomite (fig. 2). Limestone units are the Reba and Grant Lake Members of the Ashlock Formation. Identifications are based on included fossils, lithologic characteristics, and stratigraphic sequence. Maximum displacement is prob- 
ably between 450 and 500 feet and is based on stratigraphic intervals measured about 3 miles to the south. Though this is not the greatest stratigraphic throw recorded in this area, it is exemplary of this type of structure and is very large considering the small areal extent of the graben.

\section{U-DOLOMITE: LOCALITY 9}

In this graben, neither field relationship nor fossil evidence was sufficient to determine if the dolomite body was altered country rock or S-dolomite strata emplaced by faulting. The graben is bounded by the upper part of the Lexington Limestone, dominantly nodular limestone and shale of the Millersburg Member. The body lies along a northwest-trending normal fault of small displacement, downthrown on the northeast. This fault also bounds another dolomite body (locality 10) about 1.5 miles southeast of locality 9 . That occurrence has been 'tentatively classified as T-dolomite (table 1), but the distance between the two occurrences is judged to be too great for any assumed genetic relationship. The bounding fault on the northeast of the graben at locality 9 was inferred only on the basis of dolomite in outcrop and as float southwest of the fault versus limestone in nearest outcrops to the northeast. A fault would be present if the dolomite is derived from S-dolomite formations of the upper sequence; however, if the body is T-dolomite, no fault at this location would be requisite. No definitive fossils were seen at this locality, but phosphatic insoluble residues might yield conodonts that could roughly establish stratigraphic affinities. This has not been attempted for this or for the other U-dolomite bodies listed herein.

\section{T-DOLOMITE: LOCALITY 23}

One additional T-dolomite locality, that at the center of the Jeptha Knob Cryptoexplosive Structure, is worthy of special mention because of its potential significance to the understanding of circular structural features variously referred to as cryptoexplosive, cryptovolcanic, or impact structures. The term for the Kentucky structures chosen here, "cryptoexplosive," suggests only that the structures were formed by an explosive event of unknown cause. The term "cryptovolcanic" implies origin by explosion emanating from within the Earth but of unknown cause. The term "impact structure" indicates origin by impact from an extraterrestrial body, a meteorite, or a comet.

Considerable controversy exists concerning the origin of such circular features, and many detailed investigations have been made elsewhere in attempts to understand their genesis. Advocates of both the endogenetic and exogenetic schools lay claim to the Kentucky structures, though tentatively of course, because there is not yet sufficient evidence to prove their origin.
Three circular structures have been found in northcentral Kentucky. They are the Jeptha Knob and Versailles features in the study area and the Muldraugh Dome, about 40 miles to the west of the study area. Another such feature, the Middlesboro structure, is in southeastern Kentucky. All are circular in plan view, are highly brecciated, and are not mineralized at the surface; at one, the Middlesboro structure, shatter cones have been found. No pronounced gravity or magnetic anomalies are associated with either the Jeptha Knob or the Versailles features. All four appear to be closely associated with faults or with structural lineaments that may indicate the presence of deep-seated faults beneath the structures. The Muldraugh Dome is underlain by an upthrust plug of Knox Dolomite (Cambrian and Ordovician) that pierces later Ordovician strata and is overlain by Silurian and Devonian dolomite and by domed strata of Devonian and Mississippian age (A. L. Bryant, Louisville Gas and Electric Co., Louisville, Ky., written commun., 1978); thus, origin by impact is unlikely.

The mode of occurence of the dolomite at locality 23 at the center of the Jeptha Knob structure suggests, but does not prove, that the explosions that caused the structure originated at depth. The dolomite is shown on the geologic map (Cressman, 1975a) as a fault-encircled horst, though the exposures are insufficient to determine the detailed relations to the surrounding rock. The uplifted block was identified by Cressman $(1975 \mathrm{a}, \mathrm{b})$ on a lithologic basis as the Logana Member of the Lexington Limestone. This was subsequently confirmed by paleontologic identifications. This rock regionally contains a zone of silicified brachiopods that helped in identification of the unit at Jeptha Knob where the silicified brachiopods are enclosed by dolomite. Dolomite has not been found in this unit elsewhere throughout the region, either in outcrop or in drill cores. The Logana block is surrounded by limestone of the Clays Ferry Formation that locally has been deformed but not dolomitized. The Logana block has been uplifted about 450 feet from its normal stratigraphic position on the basis of stratigraphic intervals measured at considerable distance from the structure. The dolomite in this horst is an exception to the observation that Kentucky T-dolomites occur mostly on the downthrown sides of faults.

Regional S-dolomite formations cap the structure but are not deformed and thus postdate the disturbance. Two generations of dolomitization are, therefore, indicated, one that dolomitized the Logana block either during or before deformation and another that involved only the undeformed S-dolomite above.

The Logana dolomitization apparently is restricted to, and therefore related to, the structure. We cannot show incontrovertibly that the dolomitizing solutions did not come from above and selectively dolomitize only the 
Logana Member, but, inasmuch as the adjacent rocks of the Clays Ferry Formation are not dolomitized, a more reasonable assumption is that the Logana dolomitization occurred at depth before the fault emplacement of the Logana block. Therefore, more than one deformation event would be indicated, and intervening time must be allowed to accomplish the dolomitization. These reasons indicate that this structure probably resulted from several endogenetic events occurring between Late Ordovician and Middle Silurian time, the age of the oldest structurally deformed rocks and of the youngest undeformed rocks, respectively.

\section{LABORATORY INVESTIGATIONS}

The field work on fault-related dolomites has been supplemented by several laboratory studies. These include petrographic and cathodoluminescense studies, X-ray and chemical analyses, and thermal maturity determinations. Most of the laboratory work has been concentrated at the Stoner Branch locality because of clear-cut field relations and good exposures there. The studies are briefly summarized here from the work of W. C. MacQuown, Jr., and R. J. DeHaas.

Petrographic and cathodoluminescence studies of the dolomite at Stoner Branch were made by MacQuown; $\mathrm{X}$-ray analyses and field and microscopy studies were made by DeHaas. Their combined work shows that both sodic and potassic feldspars cccur as silt-sized to finesand-sized crystals at the centers of many dolomite rhombs. This was first determined from X-ray studies and the intracrystalline position established by microscopic and cathodoluminescence examination. The feldspar grains do not appear to be abraded and are believed to be authigenic crystals that formed during an early stage in the dolomitization. Separations of authigenic feldspars preparatory to attempts at $\mathrm{Rb}-\mathrm{Sr}$ and $\mathrm{K}$-Ar age-dating of the dolomite were made by DeHaas. This dolomite-enclosed feldspar may prove to be unique to T-dolomite. Extensive petrographic study of regional S-dolomite occurrences in Kentucky by Wayne A. Pryor (oral commun., 1979) of the University of Cincinnati found no nucleic feldspar in the dolomite samples collected.

The dolomite at Stoner Branch is ferroan, and crystals show successive growth stages identified by variations in iron content, which is discerned as overgrowth bands of different colors under cathodoluminescence. Latestage intercrystalline filling and partial replacement of dolomite by calcite was determined from paragenetic relations seen during the microscopic study.

Semiquantitative spectrographic and colorimetric analyses that include 11 samples from the Stoner Branch locality are shown in table 2. Samples BW-1 through BW-9 are from the collection array illustrated in figure 6. Three resistant beds were sampled across the zone of transition from essentially unaltered limestone (BW-1, $-2,-3)$, through partially dolomitic limestone (BW-4, -5, -6), to completely dolomitized material (BW-7, -8, -9). Ca: $\mathrm{Mg}$ (not given) decrease as would be expected, and the concentrations of the tested elements fall within expectable limits for normal marine carbonate rocks (Donald A. Brobst, 1978, oral commun.). The remainder of the analyses are for dolomite samples (localities shown in fig. 4) from the Winchester (BW), Lawrenceburg (BL), Versailles (BV), and Salvisa (BS) Quadrangles, except that sample BV-1 is from a limestone breccia from the Versailles Cryptoexplosive Structure. A possible explanation for the

TABLE 2.-Chemical analyses of samples

|Semiquantitative spectrographic analysis by E. L. Moser; colorimetric analysis by M. S. Erickson. N, not detected at limit of detection or at value shown; L, deterted, but below limit of determination or below value shown!

\begin{tabular}{|c|c|c|c|c|c|c|c|c|c|c|c|c|c|c|c|c|c|c|c|c|c|}
\hline \multirow{3}{*}{ Field } & \multirow{3}{*}{ Nis. } & \multicolumn{19}{|c|}{ Semiquantitative spectrographic analysis 6-step D.C. are method } & \multirow{2}{*}{$\begin{array}{c}\text { Colori- } \\
\text { metric } \\
\text { analysis }\end{array}$} \\
\hline & & $\mathrm{Fe}$ & $\mathrm{Mg}$ & $T_{1}$ & $\overline{M n}$ & B & $B_{\mathrm{it}}$ & Be & $\mathrm{Bi}$ & $\mathrm{Cd}$ & Co & $\mathrm{Cr}$ & $\mathrm{Cu}$ & $\mathrm{Ni}$ & $\mathrm{Pb}$ & $\mathrm{Sr}$ & $\bar{v}$ & $Y$ & 7r & Git & \\
\hline & & \multicolumn{3}{|c|}{ (percent) } & \multicolumn{16}{|c|}{$(\mathrm{ppm})$} & $(\mu \mathrm{pm})$ \\
\hline BW-1 & - & 0.5 & 0.7 & 0.05 & 1,000 & 5 & 50 & $\mathrm{~N}(1)$ & $N(1)$ & 2 & $N(5)$ & 5 & 7 & 7 & 7 & 500 & 10 & $N(10)$ & 50 & 1 & 400 \\
\hline BW-2 & -- & .7 & 2 & .1 & 1,000 & 10 & 70 & $\mathrm{~N}(1)$ & $\mathrm{N}(1)$ & 10 & $\mathrm{~N}(5)$ & 7 & 5 & 5 & 10 & 700 & 20 & 10 & 70 & 1.5 & 300 \\
\hline BW-3 & - & .5 & 1 & .02 & 700 & $\mathrm{~L}(5)$ & 20 & $\mathrm{~N}(1)$ & $N(1)$ & $N(2)$ & $\mathrm{N}(5)$ & 5 & 5 & $N(5)$ & 7 & 300 & $N(5)$ & $N(10)$ & 50 & 1 & 200 \\
\hline BW-4 & - & .3 & 7 & .1 & 1,000 & 30 & 150 & 1 & $\mathrm{~N}(1)$ & 3 & 15 & 10 & 15 & 20 & 20 & 100 & 50 & 20 & 150 & 5 & 350 \\
\hline BW-5 & - & .7 & 2 & .03 & 1,000 & 5 & 50 & $\mathrm{~N}(1)$ & $\mathrm{N}(1)$ & 3 & $N(5)$ & 5 & 5 & 7 & 15 & 200 & 10 & $\mathrm{~L}(10)$ & 20 & 1 & 350 \\
\hline BW-6 & -- & 1.5 & 5 & .1 & 700 & 20 & 150 & $\mathrm{~L}(1)$ & $N(1)$ & 3 & 5 & 7 & 10 & 10 & 20 & 200 & 50 & 15 & 100 & 5 & 600 \\
\hline BW-7 & - & 2 & 7 & .07 & 1,000 & 20 & 100 & $\mathrm{~L}(1)$ & $\mathrm{N}(1)$ & 5 & 7 & 7 & 10 & 10 & 20 & $\mathrm{~N}(100)$ & 20 & 15 & 50 & 3 & 400 \\
\hline BW-8 & - & 1.5 & 5 & .03 & 700 & 15 & 50 & $N(1)$ & $\mathrm{N}(1)$ & $N(2)$ & 5 & 7 & 10 & 7 & 10 & $\mathrm{~N}(100)$ & 10 & $N(10)$ & 20 & 2 & 300 \\
\hline BW-9 & - & 3 & 10 & .2 & 1,000 & 70 & 1000 & 1 & $\mathrm{~N}(1)$ & 2 & 5 & 20 & 10 & 10 & 20 & 100 & 70 & 20 & 100 & 7 & 1,000 \\
\hline$B W-10$ & & 3 & 7 & .1 & 1,000 & 50 & 100 & 1 & $N(1)$ & 5 & 10 & 20 & 15 & 15 & 10 & $N(100)$ & 50 & 20 & 50 & 5 & 650 \\
\hline $\mathrm{BW}-1$ & & 2 & 5 & .07 & 1,000 & 20 & 150 & $\mathrm{~L}(1)$ & $\mathrm{N}(1)$ & 2 & 20 & 20 & 15 & 15 & 10 & $\mathrm{~N}(100)$ & 20 & 10 & 30 & 5 & 900 \\
\hline BL-1. & $\ldots$ & 2 & 7 & .07 & 1,000 & 20 & 100 & $\mathrm{~L}(1)$ & N(1) & $N(2)$ & 10 & 10 & 10 & 15 & 5 & $\mathrm{~N}(100)$ & 20 & 15 & 20 & 3 & 300 \\
\hline BV -1 & $\ldots$ & 1 & .5 & .05 & 700 & 7 & 50 & $N(1)$ & $N(1)$ & $\mathrm{N}(2)$ & $N(5)$ & 7 & 5 & 7 & 20 & 500 & 15 & 50 & 50 & 2 & 1,700 \\
\hline BV -2 & -- & 1 & 3 & .005 & 500 & $\mathrm{~N}(5)$ & $\mathrm{N}(20)$ & $\mathrm{N}(1)$ & $\mathrm{N}(1)$ & $\mathrm{N}(2)$ & $\mathrm{N}(5)$ & 5 & 7 & 10 & 5 & $\mathrm{~N}(100)$ & 10 & $\mathrm{~L}(10)$ & $\mathrm{N}(20)$ & 1 & 800 \\
\hline BV -3 & --- & 2 & 5 & .1 & 700 & 20 & 100 & $\mathrm{~L}(1)$ & $N(1)$ & $N(2)$ & 10 & 10 & 20 & 15 & 10 & $\mathrm{~N}(100)$ & 20 & 20 & 100 & 5 & 800 \\
\hline BS-1 & --- & 1.5 & 3 & .05 & 700 & 10 & 50 & $\mathrm{~N}(1)$ & $\mathrm{N}(1)$ & $\mathrm{N}(2)$ & $N(5)$ & 7 & 10 & 10 & 5 & $\mathrm{~N}(100)$ & 15 & 10 & 20 & 2 & 700 \\
\hline BS-2 & -- & 3 & 5 & .07 & 1,000 & 20 & 100 & $\mathrm{~L}(1)$ & $N(1)$ & $N(2)$ & 30 & 7 & 20 & 20 & 10 & $\mathrm{~N}(100)$ & 20 & 30 & 30 & 5 & 600 \\
\hline $\mathrm{BS}-3$ & -- & 2 & 5 & .07 & 1,000 & 15 & 70 & $\mathrm{~L}(1)$ & $\mathrm{N}(1)$ & $\mathrm{N}(2)$ & 15 & 5 & 10 & 10 & 5 & $\mathrm{~N}(100)$ & 20 & 30 & 20 & 3 & 600 \\
\hline
\end{tabular}


high fluorine content of that sample might be that an unnoticed vug containing fluorspar was sampled. No indications of intensive mineralization in outcrop at that locality were found, though barite float occurs at a locality about 300 yards north of the structure.

Conodonts from three surface and two core-hole samples from the dolomite at Stoner Branch were analyzed colorimetrically by Anita Epstein Harris (USGS) to establish the thermal history of the rock. The method, described by Epstein and others (1977), involves the comparison of the color of conodonts from the sample with those heated to form a set of controlled standards. On exposure to increasing temperatures, the color of the organic material in the conodonts irreversibly changes; this change indicates the maximum temperature to which the rock has been subjected. The results show that the samples at Stoner Branch never exceeded a temperature of $50^{\circ} \mathrm{C}$. Acritarchs from the same samples analyzed by Stephen Jacobson of Chevron, U.S.A., Inc., indicated that the temperature never exceeded $65^{\circ} \mathrm{C}$. These analyses suggest that the fault-conducted dolomitizing solutions were either cool downward percolating waters or moderately hot hydrothermal solutions. Therefore, the direction of fluid migration was not determined. A sample of T-dolomite collected at the Jeptha Knob Cryptoexplosive Structure (locality 23) yielded the same results.

\section{SUMMARY AND CONCLUSIONS}

Detailed mapping in central Kentucky has revealed numerous occurrences of fault-related dolomite. Field evidence supported by some laboratory analyses indicates two modes of emplacement for these dolomite bodies. Some are small grabens displaced from regionally dolomitic (S-dolomite) formations much higher in the stratigraphic section. A second mode consists of inplace dolomitization of limestone country rock (T-dolomite) adjacent to faults that acted as conduits for the dolomitizing solutions. The mode of emplacement of a few bodies in the study area (U-dolomite) could not be definitely classified.

Some general field observations pertaining to T-dolomite occurrences are as follows:

1. Dolomite is commonly restricted to the downthrown sides of faults.

2. Rocks on the upthrown side show only trace amounts of disseminated dolomite similar to amounts found in unaltered limestone of the region.

3. Dolomitization appears to affect fine-grained argillaceous limestone at a greater distance from the source faults than it does the coarser grained limestone.
4. Dolomitization can obliterate all traces of most fossils even in rocks wholly composed of fossils. Crinoids and corals locally retain their original form even though dolomitized. Phosphatic fossils such as conodonts and phosphatic fillings of bryozoan zooecia and small gastropods appear commonly to withstand dolomitization as do ferruginous coatings of fossils and bedding features.

5. Dolomitization modifies original bedding to such a degree that very irregularly bedded fossilfragmental limestone may be converted to evenbedded dolomite.

6. Porosity and permeability are increased, especially where the limestone is only partly dolomitized.

7. Mineral- and petroleum-filled vugs appear to be commonly associated with this mode of dolomite emplacement.

Laboratory studies on some of the T-dolomite bodies revealed the common occurrence of feldspathic nuclei in banded ferroan dolomite crystals, indicating that T-dolomitization of the original limestone occurred as a series of crystal growth stages. Lack of rounding of many of the feldspar crystals suggests that they may be authigenic, and their nucleic position suggests that they may have formed very early in the dolomitization process. Though additional study is needed, early indications suggest that the nucleic feldspar found in T-dolomite does not occur in S-dolomite-bearing formations in Kentucky, and, thus, its presence may indicate fault-associated replacement origin. Thermal maturity studies show that the dolomitizing solutions, if hydrothermal, were only moderately hot. All samples tested had never been subject to temperatures higher than $50^{\circ} \mathrm{C}$.

Evidence for the origin of the dolomitizing solutions appears to be conflicting. At some localities, upward migration of the solutions is suggested along faults, some of which are known to extend to basement and to have been periodically active. At other localities, however, downward migration would seem more likely.

Further comparative studies between regional S-dolomite formations and the T-dolomite bodies might find some means by which they could be distinguished from one another, or, if they are truly indistinguishable, their presumed common heritage might be revealed. Conodont studies of the remaining U-dolomite bodies might identify these as T- or S-dolomites.

The recognized association between local dolomites and both Mississippi Valley-type mineral deposits and petroleum accumulations elsewhere suggest that drilling along structural lineaments where these dolomite bodies are found might be fruitful, other conditions being favorable.

If the dolomitization of the horst at the center of the 
Jeptha Knob Cryptoexplosive Structure could be shown conclusively to be related to both the circular feature and to the deep-seated fault believed to underlie it, meteorite-impact origin could be ruled out, and, because this feature can be accurately dated as latest Ordovician, another age determination would be added to our knowledge of the regional tectonic history.

\section{REFERENCES CITED}

Bass, M. N., 1960, Grenville boundary in Ohio: Journal of Geology, v, 68 , no. 6 , p. $673-677$.

Bayley, R. W., and Muehlberger, W. R., compilers, 1968, Basement rock map of the United States (exclusive of Alaska and Hawaii): U.S. Geological Survey map, scale 1:2,500,000. 2 sheets.

Berry, W. B. N., and Boucot, A. J., eds., 1970, Correlation of the North American Silurian rocks: Geological Society of America Special Paper 10, 289 p.

Black, D. F. B., 1964, Geologic map of the Versailles quadrangle, Kentucky: U.S. Geological Survey Geologic Quadrangle Map GQ-325.

-1967, Geologic map of the Coletown quadrangle, east-central Kentucky: U.S. Geological Survey Geologic Quadrangle Map GQ-644.

1968, Geologic map of the Ford quadrangle, central Kentucky: U.S. Geological Survey Geologic Quadrangle Map GQ-764.

1974, Geologic map of the Winchester quadrangle, Clark and Madison Counties, Kentucky: U.S. Geological Survey Geologic Quadrangle Map GQ-1159.

1975 , Geologic map of the Hedges quadrangle, east-central Kentucky: U.S. Geological Survey Geologic Quadrangle Map GQ-1235.

Black, D. F. B., Keller, G. R., and Johnson, R. W., Jr., 1976, Maps showing geologic structure, Bouguer gravity, and aeromagnetic intensity for part of central Kentucky. U.S. Geological Survey OpenFile Report 76-307, 12 p., 4 pls.

-1977a, Map showing structural geology, Bouguer gravity, and aeromagnetic intensity for a portion of central Kentucky, Northeast sheet Lexington, Ky., Kentucky Geological Survey.

1977b, Map showing structural geology, Bouguer gravity, and acromagnetic intensity for a portion of central Kentucky, southeast sheet: Lexington, Ky., Kentucky Geological Survey.

$1977 \mathrm{c}$, Map showing structural geology, Bouguer gravity, and aeromagnetic intensity for a portion of central Kentucky, northwest sheet: Lexington, Ky., Kentucky Geological Survey.

$-1977 d$, Map showing stuctural geology, Bouguer gravity, and acromagnetic intensity for a portion of central Kentucky, southwest sheet: Lexington, Ky., Kentucky Geological Survey.

Chavez, P. S., Jr., O'Connor, J. 'T., McMacken, D. K., and Eliason, Eric, 1979, Digital image processing techniques of integrated images and non-image data sets: ERIM International Symposium on Remote Sensing of the Environment, 13th, Ann Arbor, Mich., April 26, 1979, Proceedings [in press].

Cressman, E. R., 1968, Geologic map of the Salvisa quadrangle, central Kentucky: U.S. Geological Survey Geologic Quadrangle Map GQ-760.

-1972a, Geologic map of the I)anville quadrangle, Mercer and
Boyle Counties, Kentucky: U.S. Geological Survey Geologic Quadrangle Map GQ-985.

1972b, Geologic map of the Lawrenceburg quadrangle, Anderson and Franklin Counties, Kentucky: U.S. Geological Survey Geologic Quadrangle Map GQ-1026.

-1973, Lithostratigraphy and depositional environments of the Lexington Limestone (()rdovician) of central Kentucky: U.S. Geological Survey Professional Paper 768, 61 p., 11 pls.

1975a, Geologic map of the Waddy quadrangle, central Kentucky: U.S. Geological Survey Geologic Quadrangle Map GQ-1255.

-1975b, Geologic map of the Shelbyville quadrangle, Shelby County, Kentucky: U.S. Geological Survey Geologic Quadrangle Map GQ-1258.

(Gressman, E. R., and Noger, M. C., 1976, Tidal-flat carbonate environments in the High Bridge Group (Middle Ordovician) of ('entral Kentucky: Kentucky Geological Survey Report of Investigations 18 , ser. $10,15 \mathrm{p}$.

Dunbar, C. O., and Rodgers, John, 1957, Principles of stratigraphy: New York, John Wiley, $356 \mathrm{p}$.

Eustein, A. G., Epstein, J. B., and Harris, L. D., 1977. Conodont color alteration-an index to organic metamorphism: U.S. Geological Survey Professional Paper 995, 27 p.

Fohs, F. J., 1913, Barytes deposits of Kentucky: Kentucky Geological Survey, ser. 4, v. 1, p. 441-588.

Jillson, W. R., 1929, Geologic map of Kentucky: Kentucky Geological Survey, ser. 6.

1945 , Notes on the discovery of a faulted area in northerncentral Kentucky: Kentucky State Historical Society Register, v. 43 , no. 145 , p. $317-320$.

Jolly, J. L., and Heyl, A. V., 1964, Mineral paragenesis and zoning in the central Kentucky mineral district: Economic Geology, v. 59, no. 4, p. 596-624, and Kentucky Geological Survey Report 15, ser. $10,1964$.

Levorsen, A. I., 1967, Geology of Petroleum (2d ed.): San Francisco and London, W. H. Freeman, 724 p.

Lidiak, E. G., and Zietz, Isidore, 1976, Interpretation of aeromagnetic anomalies between latitudes $37^{\circ} \mathrm{N}$. and $38^{\circ} \mathrm{N}$. in the eastern and central United States: Geological Society of America, Special Paper 167, $37 \mathrm{p}$.

MacQuown, W. C., Jr., 1968, Geologic map of the Nicholasville quadrangle, Jessamine and Fayette Counties, Kentucky: U.S. Geological Survey Geologic Quadrangle Map GQ-767.

Moore, F. B., 1977, Geologic map of the Monterey quadrangle, Owen County, Kentucky: U.S. Geological Survey Geologic Quadrangle Map GQ-1400.

Outerbridge, W. R., 1975, Geologic map of the Austerlitz quadrangle, Clark and Bourbon Counties, Kentucky: U.S. Geological Survey Geologic Quadrangle Map GQ-1245.

Peterson, W. L., 1977, Geologic map of the Cardwell quadrangle, Washington and Mercer Counties, Kentucky: U.S. Geological Survey Geologic Quadrangle Map GQ-1379.

Robinson, L. C., 1931, The vein deposits of central Kentucky: Kentucky Geological Survey, ser. 6, v. 41, 127 p.

Shawe, F. R., and Wigley, P. B., 1974, Geologic map of the Stanford quadrangle, Boyle and Lincoln Counties, Kentucky: U.S. Geological Survey Geologic Quadrangle Map GQ-1137.

Wolcott, D. E., and Cressman, E. R., 1971, Geologic map of the Bryantsville quadrangle, central Kentucky: U.S. Geological Survey Geologic Quadrangle Map GQ-945. 


